\title{
The effect of alternative fuels injection timing on toxic substances formation in CI engines
}

The present study describes selected issues associated with the emission level in toxic exhaust gases and fuel injection timing. The study was focused on the following types of fuels: Diesel oil (the base fuel) and the other fuels were the mixture of fatty acid methyl ester with Camelina (L10 - diesel fuel with 10\% V/V FAME of Camelina and L20 - diesel fuel with 10\% V/V FAME of Camelina) was used. Fuel injection advanced angle was set for three different values - the factory setting $-12^{\circ}$ before TDC, later injection $-7^{\circ}$ and earlier injection $-17^{\circ}$. The most important conclusion is that in most measurement points registered in the same engine operating conditions, the concentration of fuel $N O_{x}$ in L1O and L2O increased but PM emissions decreased which is caused by active oxygen located in the internal structure of the fuel. This fact contributes to the rise in temperature during the combustion process. At the same time factory settings of the angle makes $\mathrm{NO}_{x}$ emissions lower and close to reference fuel.

Key words: Biofuels, diesel engine, toxic substances

\section{Introduction}

In the past few years there has been rapid development of public awareness and concern for the environment. Contamination of the environment has reached a level from which man had so far not met. It has been shown that the emission of harmful substances into the environment affects human life, the productivity of agricultural and natural ecosystems [15]. It has a direct impact on human health and contributes to respiratory illnesses; particularly allergies. Air pollution causes corrosion of metals and construction materials. Act adversely on the plants, disrupts photosynthesis and taints water and soil. On a global scale have an impact on climate change. The most characteristic examples of the risks are [5]:

- acid rains,

- the phenomenon of white smog (photochemical),

- black smog phenomenon (London),

- the greenhouse effect,

- decrease in the protective ozone layer.

Constantly tightening up the criteria for toxic exhaust emissions and decreasing oil resources are forcing the automotive industry to intensify research and finding for new technical solutions, offering the possibility of using alternative fuels and ensuring the least possible adverse impact of vehicles on the natural human environment. Reducing emissions of harmful compounds should focus primarily on reducing their formation in the engine (direct method), and then at their disposal (indirect method) [1, 2, 13, 14]. The main activities are focused on improving the combustion process in the engine by optimizing the design and implementation of additional systems, limiting the production of harmful substances in the combustion chamber. These activities are limited, since the primary task of the internal combustion engine is to produce energy in a highly effective and efficient way $[5,8,12]$.

The article focuses on the impact of different fuels $(\mathrm{ON}$, L10, L20) on formation of the toxic components at exhaust gases for different injection timing angles. This subject is moved mainly in Europe due to the origin of the plant used for production of L10 and L20 and partially was investigat- ed by authors of publications as to the effect of the injection timing on combustion process [11]. The originality of presented research results is that the authors use to power the engine mixtures of diesel oil and fatty acid methyl esters L10 and L20.

\section{Experimental apparatus and procedure}

The aim of the study is to analyze and evaluate the emission of toxic components in exhaust gases. Research was carried out on three fuels; namely, ON (diesel oil), L10, L20, and for three different angles of injection timing. Measurements related to the two standardized toxic components of exhaust gases: $\mathrm{PM}$ and $\mathrm{NO}_{\mathrm{x}}$ were conducted. These two toxic components from the exhaust were designated from other components in the study because of the highest observed differences in their concentrations during tests on engine when engine was supplied with described fuels in different operation conditions.

Experimental tests were performed on a test bench in accordance with the $\mathrm{C} 1$ test procedure and ISO 8178 [3]. For the measurement of toxic components in exhaust gases AVL CEB II gas analyzer was used. The analyzer measures the concentrations of $\mathrm{NO}_{\mathrm{x}}$ using CLD method - chemiluminescent sensor. It utilizes the phenomenon of emission of electromagnetic radiation of a wavelength 0,6-3 microns, accompanying the reaction of nitric oxide $\mathrm{NO}$ with ozone, $\mathrm{O}_{3}$. The reaction produces radiation that can be converted later into an electrical signal. This signal is proportional to the intensity of the radiation, and thus the concentration of nitric oxide in the exhaust. Measurement of particulate matter was done in real time using the unit Horiba MEXA 1230. This device provides a continuous measurement of the components of the particulate emissions. Our research results show the sum of the weights recorded of soot and soluble organic molecules.

Three fuels used during the tests, namely ON, L10 and L20. Diesel fuel is the base fuel and the other fuels are ON and the mixture of fatty acid methyl ester with camelina, which could be, on grounds of its physicochemical properties, fuel substitute for pure ON $[6,7,10]$. It is known that 
pure camelina ester is a promising future fuel because it belongs to the second generation of alternative fuels promoted and recommended for potential use in the European Union.

Table 1. Physical and chemical properties of three fuels ON, L10, L20

\begin{tabular}{|l|c|c|c|}
\hline Parameter & ON (diesel oil) & L10 & L20 \\
\hline Density $\left[\mathrm{g} / \mathrm{cm}^{3}\right]$ & 0.83 & 0.834 & 0.839 \\
\hline Viscosity $\left[\mathrm{mm}^{2} / \mathrm{s}\right]$ & 2.8 & 3 & 3,2 \\
\hline The calorific value $[\mathrm{MJ} / \mathrm{kg}]$ & 42.5 & 42 & 41 \\
\hline Cetane number & 55 & 54 & 53 \\
\hline
\end{tabular}

The test stand was based on the Perkins 1104C-E44T engine. It is a four-cylinder turbocharged diesel engine with direct fuel injection into the combustion chamber and liquid-cooling. This engine is electronically controlled, it has two ECU types: primary for engine and secondary for injection pump control. It is designed for working machines, agricultural tractors and power generators $[4,9,10]$. The tests measuring system consists of four measurement channels: (i) the pressure in the combustion chamber, (ii) the angle of rotation of the crankshaft, (iii) the toxic exhaust emissions, and (iv) the particulate emissions.

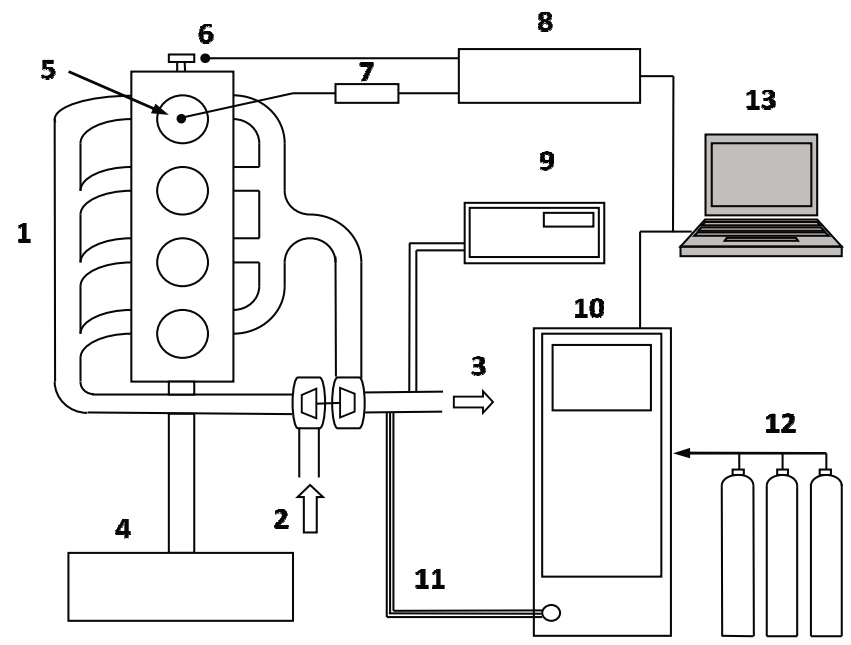

Fig. 1. Diagram of the test bench: 1 - engine PERKINS 1104C-E44T;

2 - air inlet; 3 - exhaust; 4 - brake; 5 - piezoelectric pressure sensor;

6 - crankshaft angle sensor; 7 - amplifier; 8 - indicating device;

9 - Horiba MEXA 1230 unit; 10 - AVL CEB II gas analyzer; 11 - heated route; 12 - reference gases; 13 - PC computer

\section{Results and discussion}

Because of the inaccuracy of instruments and testing methods, measuring result is always different from the actual measured values. Research was conducted on Perkins 1104C-E44TA and carried out using engine dynamometer and gas analyzers: AVL CEB II and Horiba MEXA 1230. Both analyzers have the same class of measuring which is $5 \%$ of maximum range of measurement.

The results are shown in Figures below. They presented as speed and load characteristics for $\mathrm{n}=1400 \mathrm{rpm}$, that is crankshaft rotation speed of maximum torque. The results are presented for the three previously mentioned types of fuel (ON, L10, L20) at an angle of fuel injection timing set for three different values labeled - A, B, C. The injection advance angle $\mathrm{A}$ is the factory setting $-12^{\circ}$ before TDC, value $\mathrm{B}$ causes subsequent injection angle by about $5^{\circ}$ after
$\mathrm{A}$, and setting $\mathrm{C}$ is earlier injection of around $-5^{\circ}$ before $\mathrm{A}$. Studies of toxic emissions for three fuels at three injection timing settings were conducted in accordance with test $\mathrm{C} 1$.

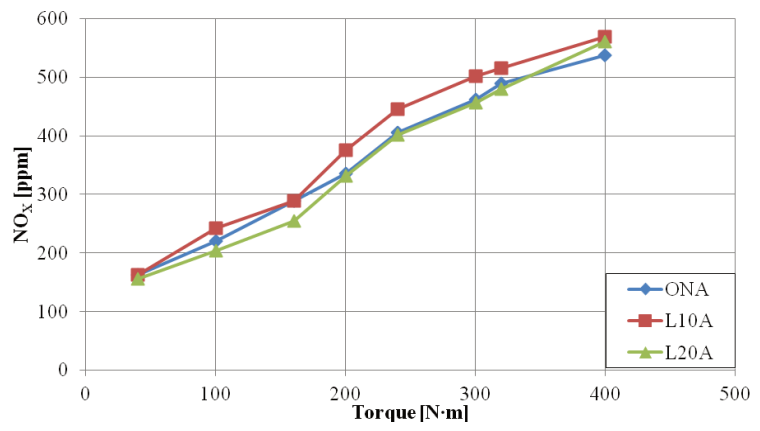

Fig. 2. $\mathrm{NO}_{\mathrm{x}}$ concentration for injection timing $\mathrm{A}$ and $\mathrm{n}=1400 \mathrm{rpm}$

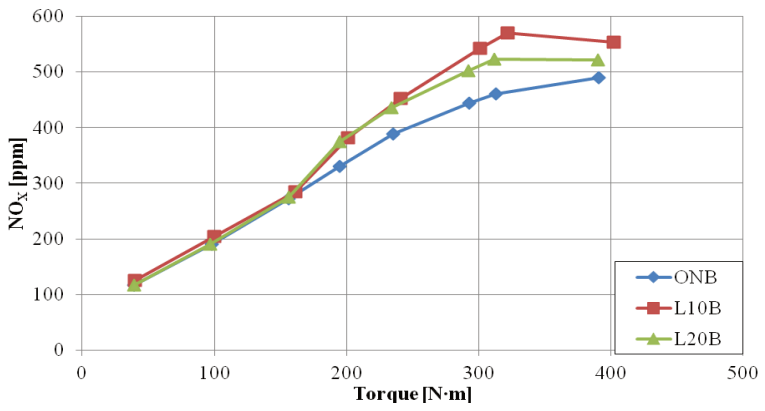

Fig. 3. $\mathrm{NO}_{\mathrm{x}}$ concentration for injection timing $\mathrm{B}$ and $\mathrm{n}=1400 \mathrm{rpm}$

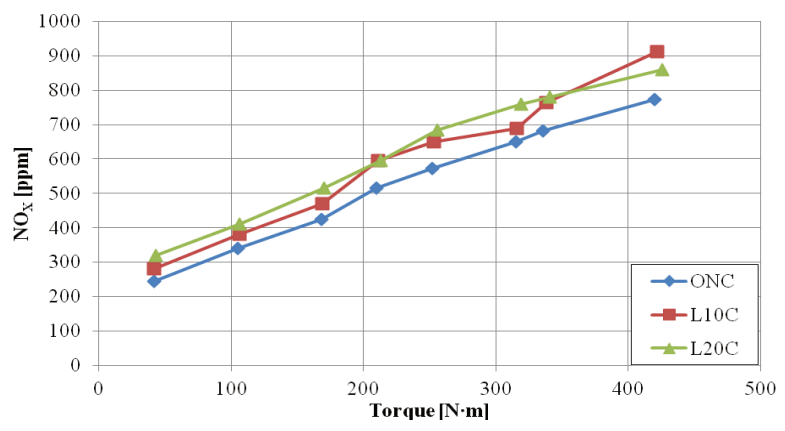

Fig. 4. $\mathrm{NO}_{\mathrm{x}}$ concentration for injection timing $\mathrm{C}$ and $\mathrm{n}=1400 \mathrm{rpm}$

Comparing the concentration of toxic components shows that for each injection angle, the highest concentration of the $\mathrm{NO}_{\mathrm{x}}$ was observed in the case of fuel L20, whereas the lowest pertained to fuel ON. The biggest difference in $\mathrm{NO}_{\mathrm{x}}$ formation was detected for fuels L20 and $\mathrm{ON}$ when injection timing angle $\mathrm{C}$ was set. Mentioned difference amounts to approx. 25\%. (cf. Fig. 4).

The concentration of PM is the smallest in the case of fuel L20, and the largest for ON. The difference between the concentration of PM for fuel $\mathrm{ON}$, and the concentration of PM for L20 when injection timing angle $\mathrm{C}$ was set (cf. Fig. 7) is approx. $35 \%$ for a maximum load of the engine.

The results shown in Figures 8-13 include speed and load characteristics carrying at $\mathrm{n}=2000 \mathrm{rpm}$, that corresponds to the crankshaft rotation speed of the maximum power. Values of $\mathrm{NO}_{\mathrm{x}}$ for all angles and fuels are almost identical. The lowest values of $\mathrm{NO}_{\mathrm{x}}$ are obtained for angle B (cf. Fig. 9). 


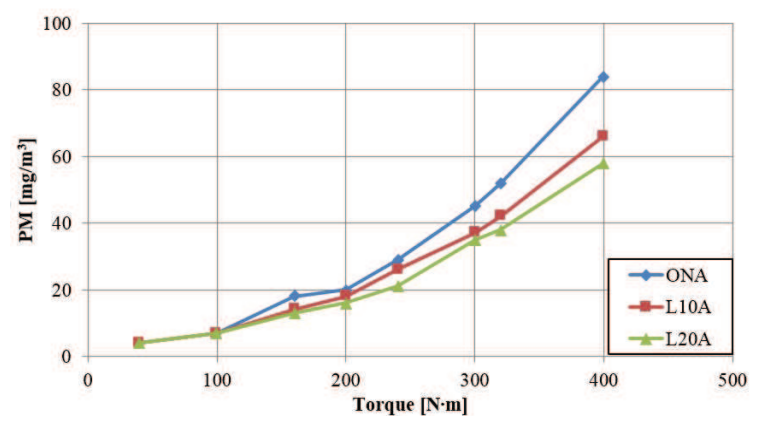

Fig. 5. PM for injection timing A and $n=1400 \mathrm{rpm}$

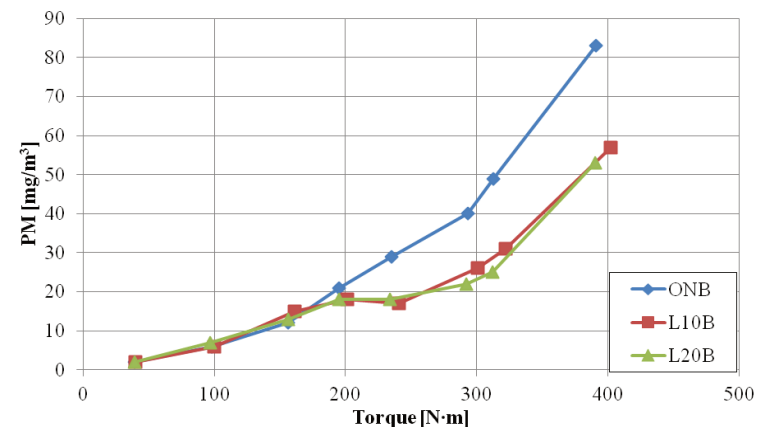

Fig. 6. PM for injection timing B and $\mathrm{n}=1400 \mathrm{rpm}$

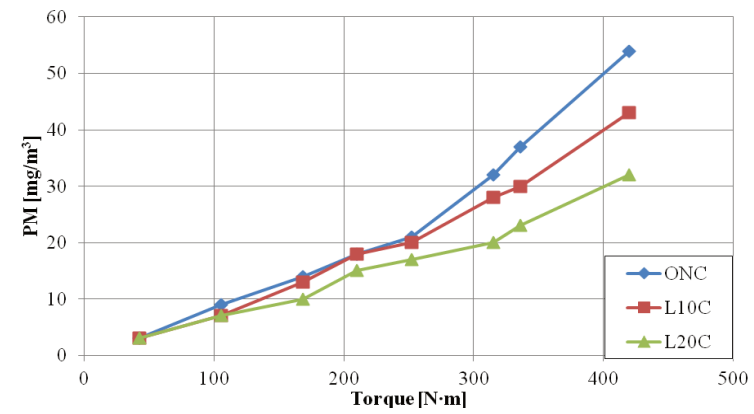

Fig. 7. $\mathrm{PM}$ for injection timing $\mathrm{C}$ and $\mathrm{n}=1400 \mathrm{rpm}$

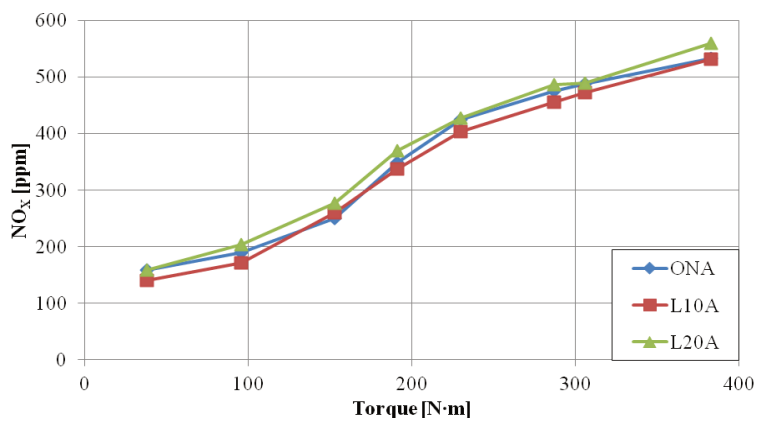

Fig. 8. $\mathrm{NO}_{\mathrm{x}}$ concentration for injection timing $\mathrm{A}$ and $\mathrm{n}=2000 \mathrm{rpm}$

The concentration of PM is the smallest for fuel L10, and almost identical for ON and L20. The difference between the concentrations of PM for fuel ON, L20 and L10 (cf. Figures 11 and 12) at injection timing angles A and B is approx. $60 \%$ for the maximum load of the engine.

In order to finally confirm the test results, the authors plan in the future to investigate the combustion process and associate it with the results of exhaust gas emissions levels.

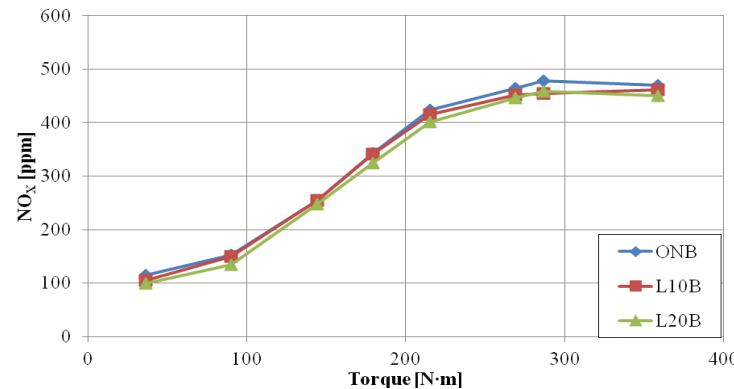

Fig. 9. $\mathrm{NO}_{\mathrm{x}}$ concentration for injection timing $\mathrm{B}$ and $\mathrm{n}=2000 \mathrm{rpm}$

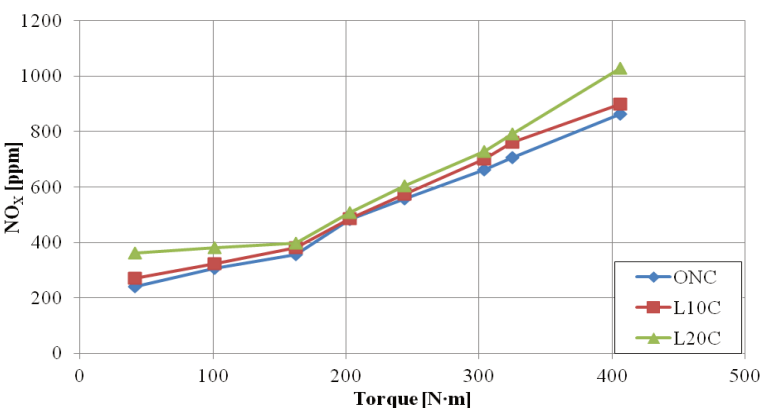

Fig. 10. $\mathrm{NO}_{\mathrm{x}}$ concentration for injection timing $\mathrm{C}$ and $\mathrm{n}=2000 \mathrm{rpm}$

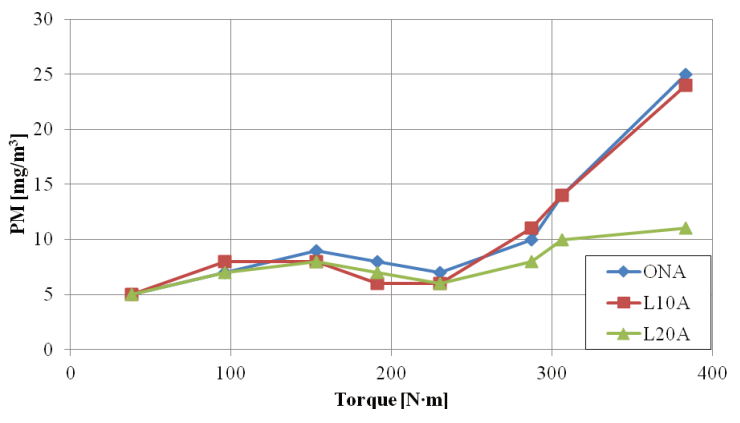

Fig. 11. PM for injection timing $\mathrm{A}$ and $\mathrm{n}=2000 \mathrm{rpm}$

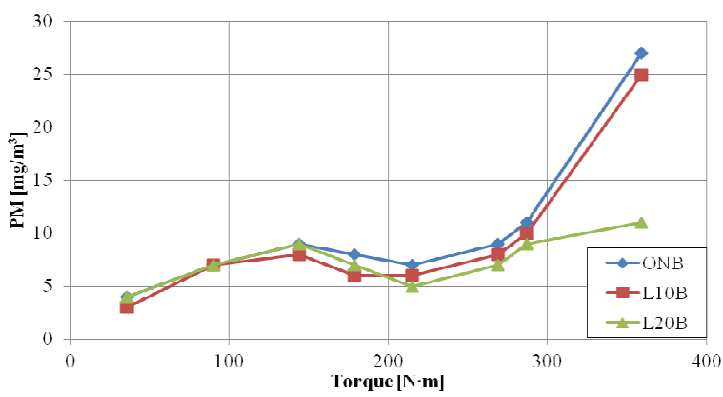

Fig. 12. PM for injection timing $B$ and $n=2000 \mathrm{rpm}$

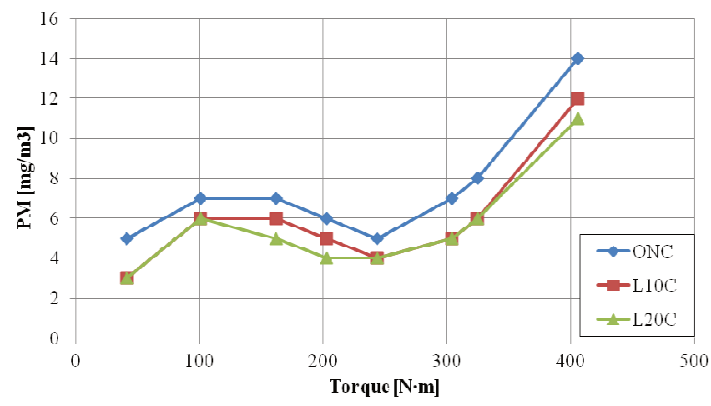

Fig. 13. PM for injection timing $\mathrm{C}$ and $\mathrm{n}=2000 \mathrm{rpm}$ 


\section{Conclusions}

The results of experimental studies illustrate the difference in emissions of toxic components in exhaust gases $\left(\mathrm{NO}_{\mathrm{x}}\right.$ and $\left.\mathrm{PM}\right)$. The study was carried out for two characteristic crankshaft rotation speeds (corresponding to maximum power and maximum torque of the engine) as a function of load. In addition, the study presented different setting of the fuel injection timing with respect to the concentrations of these two toxic components.

Analyzing the test results for two different characteristic speeds the following conclusion can be made:
- in most measurement points registered in the same engine operating conditions when fuel L10 and L20 is used, $\mathrm{NO}_{\mathrm{x}}$ concentration increases, $\mathrm{PM}$ emissions decreases which is caused by active oxygen content in the internal structure of the fuels and thus contributing to the rise in temperature during the combustion process,

- the highest concentrations of $\mathrm{NO}_{\mathrm{x}}$ and the smallest PM were recorded at maximum fuel injection timing angle (angle C). The reason for it was the advanced start of the combustion process (perhaps even before TDC) and thus causing the higher level of maximum pressure and temperature of the working medium in the combustion chamber.

\section{Nomenclature}

CLD chemiluminescent sensor method

ECU electronic control unit

FAMEfatty acid methyl ester

L10 diesel fuel with $10 \% \mathrm{~V} / \mathrm{V}$ fatty acid methyl ester of Camelina oil

L20 diesel fuel with $20 \% \mathrm{~V} / \mathrm{V}$ fatty acid methyl ester of Camelina oil
NO nitric oxide

$\mathrm{NO}_{\mathrm{x}}$ oxides of nitrogen

ON diesel fuel

PM particulate matter

TDC top dead center

\section{Bibliography}

[1] AGARWAL, A.K. Biofuels (alcohols and biodiesel) applications as fuels for internal combustion engines. Progress in Energy and Combustion Science. 2007, 33, 233-71.

[2] AMBROZIK, A., AMBROZIK, T., ŁAGOWSKI, P. Fuel impact on emissions of harmful components of the exhaust gas from the ci engine during cold start-up. Eksploatacja i Niezawodność - Maintenance and Reliability. 2015, 17(1), 95-99.

[3] AMBROZIK, A., ŁAGOWSKI, P. Podstawy sterowania i diagnostyki silników o zapłonie samoczynnym, Wydawnictwo Politechniki Świętokrzyskiej, 2016. Kielce.

[4] Instructions for Perkins 1100 Series. (IFP).

[5] KRUCZYŃSKI, S.W. Filtracja cząstek stałych w spalinach pojazdów samochodowych, Instytut Naukowo-Wydawniczy SPATIUM, 2011, Radom.

[6] KRUCZYŃSKI, S.W. Performance and emission of CI engine fuelled with camelina sativa oil. Energy Conversion and Management. 2013, 65, 1-6.

[7] KRUCZYNSSKI, S.W., ORLIŃSKI, P. Combustion of methyl esters of various origins in the agricultural engine. Indian Journal of Engineering and Materials Sciences. 2013, 20, 483-491.

[8] MOSER, B.R. Fuel property enhancement of biodiesel fuels from common and alternative feedstocks via complementary blending. Renewable Energy. 2016, 85, 819-825.
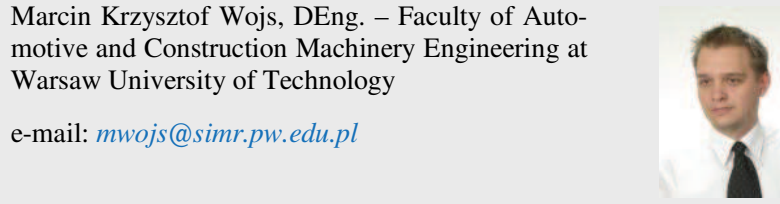

Jakub Lasocki, DEng. - Faculty of Automotive and Construction Machinery Engineering at Warsaw University of Technology.

e-mail:j.lasocki@simr.pw.edu.pl
[9] ORLIŃSKI, P, WOJS, M. K., MAZURUK, P. Budowa stanowiska do badań paliw eksperymentalnych płynnych wykorzystującego silnik rolniczy o zapłonie samoczynnym. Zeszyty Naukowe Instytutu Pojazdów. 2013, 1(92), 167-172.

[10] ORLIŃSKI, P. Wybrane zagadnienia procesu spalania paliw pochodzenia roślinnego $\mathrm{w}$ silniku o zapłonie samoczynnym, Instytut Naukowo-Wydawniczy SPATIUM, 2013, Radom.

[11] ORLIŃSKI, P. Ocena wpływu zmiany kąta wyprzedzenia wtrysku na proces wydzielania ciepła $\mathrm{w}$ silniku rolniczym zasilanym biopaliwami. Logistyka. 2014, 3, 4843-4854.

[12] PRZYBYŁA, P. Studium stosowania biopaliw gazowych do zasilania silników spalinowych, Wydawnictwo Politechniki Ślaskiej. 2015, Gliwice.

[13] RAKOPOULOS, C.D., ANTONOPOULS, K.A., RAKOPOULOS, D.C., HOUNTALAS, D.T., GIAKOURNIS, E.G. Comparative Performance and emission study of DI diesel engine with vegetable oil. Energy Conversion and Management. 2006, 47, 3272-87.

[14] REHMAN, H., PHADATARE, A.G. Diesel Engine emission and performance from blends of karanja methyl ester and Diesel. Biomass and Bioenergy. 2004, 27, 393-297.

[15] REIF, K. Gasoline engine management: systems and components. Springer Fachmedien. 2015, Wiesbaden.

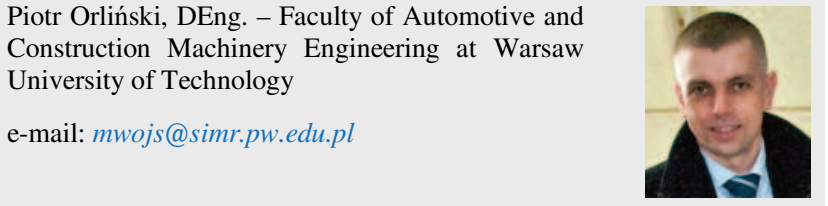

